\title{
Effect of surface treatments on the bond strength of a zirconia-reinforced ceramic to composite resin
}

\author{
Efeito de tratamentos de superfície sobre a \\ resistência de união entre cerâmica reforçada \\ por zircônia e resina composta
}

\begin{abstract}
Alvaro Della Bona ${ }^{(a)}$
Márcia Borba ${ }^{(b)}$

Paula Benetti(c)

Dileta Cecchetti ${ }^{(d)}$
\end{abstract}

\begin{abstract}
(a) PhD in Biomaterials, Research Coordinator and Senior Professor of Prosthodontics and Occlusion, Dental School; (d) MSc in Statistics, Professor of the Institute of Biological Sciences - University of Passo Fundo.
\end{abstract}

(b) MSc Student, Dental Materials, University of São Paulo.

(c)MSc Student, Operative Dentistry, Federal University of Pelotas.

\begin{abstract}
The objective of this study was to evaluate the tensile $\left(\sigma_{t}\right)$ and shear bond strength $\left(\sigma_{s}\right)$ of a glass-infiltrated alumina-based zirconia-reinforced ceramic (IZ - Vita In-Ceram Zirconia) to a composite resin, testing the hypothesis that silica coating (SC - Cojet, 3M-Espe) produces higher bond strength values than other ceramic surface treatments. Specimens were fabricated and tested according to the manufacturers' instructions, and to ISO6872 and ISO11405 specifications. Sixty IZ disk specimens were polished through $1 \mu \mathrm{m}$ and divided into 3 groups $(\mathrm{n}=20)$ according to the following surface treatments: HF - 9.5\% hydrofluoric acid (Ultradent) for $1 \mathrm{~min}$; SB - sandblasting with $25-\mu \mathrm{m}$ aluminum oxide particles for $10 \mathrm{~s}$; SC - silica coating for $10 \mathrm{~s}$. Silane (3M-Espe), adhesive (Single Bond, 3M-Espe) and a composite resin cylinder (Z100, 3M-Espe) were applied and polymerized to the treated bonding area $(3.5 \mathrm{~mm}$ in diameter). Ten specimens from each group $(n=10)$ were tested for $\sigma_{t}$ and ten specimens were tested for $\sigma_{s}$, using a universal testing machine (EMIC DL 2000) at a crosshead speed of $1 \mathrm{~mm} / \mathrm{min}$. The data were statistically analyzed by ANOVA and Tukey tests $(\alpha=0.05)$. The mean and standard deviation values $(\mathrm{MPa})$ and statistical groupings for $\sigma_{\mathrm{t}}$ were: $\mathrm{HF}-3.5 \pm 1.0 \mathrm{a}$; $\mathrm{SB}-7.6 \pm 1.2 \mathrm{~b}$; and SC $-10.4 \pm 1.8 \mathrm{c}$. For $\sigma_{\mathrm{s}}$, the values were: HF $-10.4 \pm 3.1 \mathrm{~A}$; SB $-13.9 \pm 3.1 \mathrm{~B}$; and SC $-21.6 \pm 1.7 \mathrm{C}(\mathrm{p}<0.05)$. The groups presented the same statistical ranking of mean values for both test methods. The SC-treated IZ ceramic presented a significant increase in mean bond strength values for both test methods, confirming the study hypothesis.
\end{abstract}

Descriptors: Ceramics; Composite resins; Tensile strength; Shear strength.

Resumo: $\mathrm{O}$ objetivo deste estudo foi avaliar a resistência adesiva à tração $\left(\sigma_{\mathrm{t}}\right)$ e ao cisalhamento $\left(\sigma_{s}\right)$ de uma cerâmica à base de alumina infiltrada por vidro e reforçada com zircônia (IZ- Vita In-Ceram Zircônia) à resina composta, testando a hipótese de que o sistema de silicatização (SC- Cojet, 3M-ESPE) produz valores maiores de resistência adesiva do que demais tratamentos de superfície utilizados. Sessenta corpos-de-prova (cp) em forma de disco da IZ foram fabricados e testados de acordo com as instruções dos fabricantes e as normas ISO6872 e ISO11405. Após polimento até $1 \mu \mathrm{m}$, os cp foram divididos em 3 grupos $(\mathrm{n}=20)$ de acordo com o tratamento de superfície aplicado: HF - ácido hidrofluorídrico a $9,5 \%$ (Ultradent) por $1 \mathrm{~min}$; SB - jateamento com óxido de alumínio $25 \mu \mathrm{m}$ por $10 \mathrm{~s}$; SC - silicatização por $10 \mathrm{~s}$. Silano (3M-Espe), adesivo (Single Bond, 3M-Espe) e um cilindro resinoso (Z100, 3M-Espe) foram aplicados na área de adesão (3,5 mm de diâmetro) e fotoativados. Dez cp por grupo $(\mathrm{n}=10)$ foram testados para $\sigma_{\mathrm{t}}$ e os outros $10 \mathrm{cp}$ para $\sigma_{\mathrm{s}}$ em uma máquina de ensaios universal (EMIC DL 2000) com velocidade de $1 \mathrm{~mm} /$ min. Os resultados foram analisados estatisticamente por ANOVA e Tukey $(\alpha=0,05)$. Os valores médios e desvio padrão $(\mathrm{MPa})$ para $\sigma_{\mathrm{t}}$ foram: $\mathrm{HF}-3,5 \pm 1,0 \mathrm{a}$; $\mathrm{SB}-7,6 \pm 1,2 \mathrm{~b}$; SC - 10,4 $\pm 1,8 \mathrm{c}$. Para $\sigma_{\mathrm{s}}$, os resultados foram: HF - 10,4 $\pm 3,1 \mathrm{~A}$; SB $-13,9 \pm 3,1 \mathrm{~B}$; SC $21,6 \pm 1,7 \mathrm{C}(\mathrm{p}<0,05)$. Os grupos mostraram o mesmo ranqueamento estatístico de valores em ambos os testes. A IZ tratada com SC demonstrou aumento significativo na média de resistência adesiva em ambos os testes, confirmando a hipótese inicial.

Descritores: Cerâmica; Resinas compostas; Resistência à tração; Resistência ao cisalhamento.
Received for publication on May 17, 2006 Sent for alterations on Jun 21, 2006 Accepted for publication on Sep 21, 2006 


\section{Introduction}

Restoring partially destructed teeth using indirect ceramic restorations such as inlays, onlays and laminate veneers has been encouraged by the development of adhesive materials and techniques. Adhesive techniques allow the brittle and "fragile" ceramic to become a reliable tooth-restoration system with an adequate stress distribution to the underlying tooth structure. ${ }^{5}$

New high crystalline content ceramic systems have been developed in an attempt to improve the esthetics and strength of metal-free restorations. ${ }^{3,17}$ They are high flexural strength systems with the ability of transmitting the colour of the supporting tooth structure. ${ }^{10}$ These new systems include lithium disilicate ceramics (IPS Empress 2, Ivoclar), glass infiltrated alumina and zirconia systems (In-Ceram, Vita) and high-density alumina or zirconia ceramic systems (Procera, Nobel Biocare; Cercon, Dentsply Ceramco; Lava, 3M-ESPE).

In the fabrication of ceramic structures by the In-Ceram systems, an alumina-based porous framework is infiltrated with a lanthanum oxidebased glass. ${ }^{10,16}$ This high crystalline content ceramic structure has a flexural strength that is three to four times higher than that of feldspathic ceramics. $^{10,22}$ The toughening mechanisms of the In-Ceram structure is based on crack deflection and impediment by the alumina particles, which deviate or block the crack propagation, and the pre-stressing mechanism where an area of compressive stress in the glass around alumina particles may lead to crack deflection. ${ }^{10}$

The In-Ceram Alumina (IA) can be used for single restorations ${ }^{13,19}$ and anterior bridges, yet it is not recommended for posterior fixed prosthesis. ${ }^{21}$ Therefore, Vita developed the In-Ceram Zirconia (IZ), ${ }^{11}$ a stronger and tougher material for threeunit posterior fixed bridges. Fabrication of IA and IZ is similar, but there is an addition of about $35 \%$ of partially stabilized zirconia oxide. ${ }^{2,11}$

Guazzato et al. ${ }^{11}$ (2002) employed X-ray diffraction to determine the phases of In-Ceram Alumina and IZ at each stage of processing and on the surface of specimens fractured during testing. Analysis of IZ revealed a crystalline characteristic with well defined peaks of alumina crystals and the tetragonal and monoclinic phases of zirconia. During processing, there was variation in the amount of monoclinic content, which was reduced to its minimum level after sinterization and reached its maximum value after polishing and fracture.

However, despite its high strength and favorable esthetics, the In-Ceram system seems to produce unreliable bonding to resin with the utilization of conventional surface treatments. Studies have reported on inadequate retentive ceramic surfaces after acid etching. In addition, the chemical bond from silane seems to be insufficient because of the reduced amount of silica in the IZ.16,22

Acid etching increases the surface area and the wettability of ceramics, changing their surface energy and the bonding potential of ceramic to resin. ${ }^{6}$ However, the microstructure of the In-Ceram system is composed of acid-resistant alumina. ${ }^{20,22}$ Thus, the acid etching does not produce significant topographic alterations in ceramics with high crystalline content, reducing the bond with the resin cement. ${ }^{4}$

Sandblasting with aluminum oxide particles is a surface treatment option that produces irregularities in acid-resistant ceramics. However, some studies reported that sandblasting the In-Ceram ceramics may be effective for the initial bond to some luting agents, yet it is not stable, since it presents failure when specimens are stored for extended periods in artificial saliva and submitted to thermocycling in water. ${ }^{15,23}$ This may be due to the fact that this treatment creates surface irregularities without micromechanical retention. ${ }^{15}$

Application of a silica coat on ceramics with high crystalline (low silica) content, as In-Ceram, has been used as an experimental surface treatment method. This technology was initially developed for metals to increase bonding to resins. The silica coating systems include the Rocatec and Cojet from ESPE (Germany) and the Silicoater MD from Heraeus Kulzer (Germany).

Cojet is an in-office silica coating system that uses $30-\mu \mathrm{m}$ silica-modified $\mathrm{Al}_{2} \mathrm{O}_{3}$ particles (Cojet-Sand) blasted to the surface, followed by the application of a silane agent (ESPE-Sil). ${ }^{9}, 12$ These silica coating systems have showed adequate bond strength val- 
ues in several studies. ${ }^{1,8,9,12,14-18}$ Kern, Thompson ${ }^{16}$ (1994) analyzed the composition and morphology of In-Ceram ceramic submitted to different treatments and observed an effective increase in the silica content after using the Rocatec system compared to Silicoater MD and sandblasting with aluminum oxide, favoring the action of silane on resin bonding. A similar study evaluated these alternative adhesive methods, investigating the stability of bonding by storage in artificial saliva and thermocycling, which also revealed the highest bond strengths for the Rocatec system, which also presented stable bond strength, whereas the bond strength values for Silicoater MD were drastically reduced after 150-day storage. ${ }^{15}$ In addition, the shear bond strengths of resin cements to the In-Ceram ${ }^{17}$ and Procera AllCe$\mathrm{ram}^{1}$ ceramics and a zirconia-based ceramic ${ }^{8}$ were also investigated. The results revealed a higher bond strength after silica coating.

Several mechanical tests may be used to evaluate the bond strength between ceramic and resin. The shear test is the most popular, yet it has some limitations. This test often induces failure away from the bonding interface, which impairs the measurement of the interfacial bond strength. There are also limitations in standardization, because of different test protocols using various shapes of load points and different distances of load application. Therefore, the careless use of this test may produce inadequate bond strength values and reduce future improvements in bonding systems. ${ }^{4,7}$

It has been shown that tensile bond strength tests allow a more uniform interfacial stress distribution, however the test's main problem is to maintain the specimen alignment during testing. ${ }^{4}$ The reduced bonding area $\left(<2 \mathrm{~mm}^{2}\right)$ in the microtensile test leads to higher bond strength values and cohesive failures at the adhesive zone. This probably occurs because the specimens have fewer structural defects due to the reduced test area. These defects are areas of stress concentration and crack propagation, which may cause adhesive failure at lower values than expected. ${ }^{5}$

The objective of this study was to evaluate the tensile $\left(\sigma_{t}\right)$ and shear bond strength $\left(\sigma_{s}\right)$ of a glassinfiltrated alumina-based zirconia-reinforced ce- ramic (IZ) to a composite resin material, testing the hypothesis that silica coating (SC) produces higher bond strength values than other ceramic surface treatments, such as acid etching (HF) and sandblasting (SB).

\section{Material and Methods}

Disc-shaped specimens of Vita In-Ceram Zirconia (Vita Zahnfabrik, Bad Sackingen, Germany) were fabricated following the manufacturer's instructions and one surface of each disc was polished through $1 \mu \mathrm{m}$ diamond paste. The discs were embedded in acrylic resin using metal rings from the Bencot Multi-T system (Danville Engineering Inc., San Ramon, CA, USA), leaving the polished ceramic surface up. The specimens' bonding area was limited $(\mathrm{A}=3.5 \mathrm{~mm}$ in diameter $)$ and they were divided into 3 groups $(\mathrm{n}=20)$ according to the following surface treatments:

- HF - 9.5\% hydrofluoric acid (Ultradent porcelain etch, Ultradent Dental Products, South Jordan, UT, USA) was applied for $1 \mathrm{~min}$;

- SB - sandblasting (Handiblaster, Chameleon Dental Products, Kansas City, KS, USA) with $25-\mu \mathrm{m}$ aluminum oxide particles for $10 \mathrm{~s}$, applied perpendicularly to the surface at a $10-\mathrm{mm}$ distance and pressure of $30 \mathrm{psi}$;

- SC - silica coating using the Cojet system (Cojet, 3M-Espe, Seefeld, Germany). The Cojet-Sand was blasted to the surface for $10 \mathrm{~s}$ using the same parameters as for samples in the SB group.

After treatment, the ceramic surfaces were rinsed with air/water spray for $30 \mathrm{~s}$ (except for the SC group), air-dried, and silane (Rely-X Ceramic Primer, 3M-Espe, St. Paul, MN, USA) was applied, allowing enough time to evaporate. Each specimen was placed in the Bencor Multi-T setup to build up the resin composite cylinder on the treated ceramic surface. Then, two consecutive coats of the adhesive (Single Bond, 3M-Espe, St. Paul, MN, USA) were applied, gently dried and light cured (XL1500, $3 \mathrm{M}$ Dental Products) for $10 \mathrm{~s}$ at a light intensity of $400 \mathrm{~mW} / \mathrm{cm}^{2}$. The composite resin (Z100, 3M-Espe, St. Paul, MN, USA) was incrementally built up ( $2 \mathrm{~mm}$ layers) to fill the cylinder. All 2-mm increments were light-cured for $40 \mathrm{~s}$. 
Half of the specimens in each group $(n=10)$ were tested for tensile bond strength $\left(\sigma_{t}\right)$ and the other half $(\mathrm{n}=10)$, for shear bond strength $\left(\sigma_{\mathrm{s}}\right)$, following the ISO standards 6872 and 11405. Both tests were performed in a universal testing machine (EMIC DL 2000, Equipamentos e Sistemas de Ensaio LTDA., São José dos Pinhais, Paraná, Brazil) at a crosshead speed of $1 \mathrm{~mm} / \mathrm{min}$ until fracture. The load to failure ( $\mathrm{F}$ in $\mathrm{N}$ ) was recorded, the mean tensile and shear bond strength values (in $\mathrm{MPa}$ ) were calculated $(\sigma=$ F/A $)$ and statistically analyzed using one-way ANOVA and Tukey tests $(\alpha=0.05)$. The fractured ceramic surfaces were analyzed by light microscopy.

\section{Results}

The mean values and standard deviations of tensile bond strength $\left(\sigma_{t}\right)$ and shear bond strength $\left(\sigma_{s}\right)$ and the statistical groupings are shown in Table 1. The mean $\sigma_{\mathrm{t}}$ and $\sigma_{\mathrm{s}}$ values were significantly different for all groups $(\mathrm{p} \leq 0.01)$, with the SC-treated surfaces showing the highest mean values for both tests.

Light microscopy analysis of the fractured surfaces demonstrated that all specimens fractured at the adhesive interface, leaving small areas of resin on the ceramic surface, characterizing a cohesive fracture at the interface. However, in both tests, the areas of remaining resin on the ceramic surface presented decreasing size and amount in the following order of groups: $\mathrm{SC}>\mathrm{SB}>\mathrm{HF}$. These observations of qualitative analysis of the fracture pattern agree with the mean values obtained for the different surface treatments $(S C>S B>H F)$, regardless of the type of bond strength test.

Table 1 - Tensile $\left(\sigma_{t}\right)$ and shear $\left(\sigma_{s}\right)$ bond strength mean and standard deviation values (MPa) followed by the statistical groupings for all experimental groups.

\begin{tabular}{c|c|c}
\hline Groups & $\sigma_{\dagger}(\mathrm{MPa})^{*}$ & $\sigma_{s}(\mathrm{MPa})^{*}$ \\
\hline $\mathrm{HF}$ & $3.5 \pm 1.0 \mathrm{a}$ & $10.4 \pm 3.1 \mathrm{~A}$ \\
\hline $\mathrm{SB}$ & $7.6 \pm 1.2 \mathrm{~b}$ & $13.9 \pm 3.1 \mathrm{~B}$ \\
\hline $\mathrm{SC}$ & $10.4 \pm 1.8 \mathrm{c}$ & $21.6 \pm 1.7 \mathrm{C}$ \\
\hline
\end{tabular}

*Values followed by similar letters in the same column did not present statistical difference $(p \leq 0.05)$.

\section{Discussion}

The results of this study agree with the findings of some investigations, ${ }^{3,8,17,18,22}$ which found that HF etching does not produce effective retention in alumina- and zirconia-based ceramics. According to Della Bona, Anusavice ${ }^{3}$ (2002), the differences in the microstructure and composition of ceramics control the development of micromechanical retention produced by acid etching. They suggested that the chemical reactivity of some single phase materials depends on the crystallographic orientation. In polycrystalline materials, etching characteristics vary according to the type of crystal. Atoms around the edges of crystals are more chemically reactive and are dissolved faster than those inside the crystal, leading to the formation of small grooves around the crystals after acid etching. They also observed that the surface of alumina particles did not change by acid etching. ${ }^{3}$ Dérand, Dérand ${ }^{8}$ (2000) examined the surface treatments for a zirconia ceramic and also showed that HF etching produced the lowest bond strengths. These authors ${ }^{8}$ also observed that sandblasting the zirconia ceramic with aluminum oxide particles produced an irregular pattern, with little influence on the bond strength.

Therefore, In-Ceram Zirconia, as a zirconia-reinforced alumina-based ceramic with acid-resistant characteristics, ${ }^{20,22}$ should not be effectively HFetched due to the low amount of glass phase. ${ }^{18}$

In comparison to the present study, Özcan, Vallittu $^{18}$ (2003) found similar mean shear bond strength values for the IZ ceramic treated with hydrofluoric acid (8.1 MPa), which was significantly lower than the mean values for the groups blasted with aluminum oxide particles (16.5 MPa) and the group treated with the Rocatec system (17.4 MPa).

Sandblasting with aluminum oxide particles revealed significantly higher mean $\sigma_{\mathrm{t}}$ and $\sigma_{\mathrm{s}}$ values than HF etching, yet the values were significantly lower that those of the SC-treated group ( $\mathrm{p} \leq 0.01$ ). This may be explained because silane is bonded to the silica present on the ceramic surface and the IZ contains a small amount of silica in its composition, which impairs the action of silane. ${ }^{15}$

The Cojet system is composed of blasted silicamodified $\mathrm{Al}_{2} \mathrm{O}_{3}$ particles, which promote surface 
roughness and a silica coat for resin bonding via silane agents. ${ }^{1}$ This tribochemical reaction produces a high temperature contact area that can hold the blasted particles and/or the silica layer on the ceramic surface. ${ }^{12}$ Microscopic analysis of the blasted surface reveals a thin and microretentive layer, 9,22 which should increase the bond strength to resin. ${ }^{1}$ This adhesive mechanism explains the high bond strength values observed for the SC-treated group, thus making for an interesting option for surface treatment of high crystalline ceramics.

Frankenberger et al. ${ }^{9}$ (2000) evaluated the shear bond strength of composite resin to porcelain-fusedto-metal and metal-free restorations after silica coating or etching with $5 \%$ hydrofluoric acid. The authors reported that silica coated ceramics showed equal or significantly higher bond strength values than the acid etched ceramics. The higher bond strength values for the silica coated ceramics were explained by two mechanisms that improve the bonding to composite resin. First, the surface roughness resulted from air abrasion, providing a larger surface area for micromechanical retention. Second, it improved the chemical bond since the silica coated surface promotes better bonding with silane and resin adhesives. Haselton et al. ${ }^{12}$ (2001) conducted a similar study and also concluded that the silica coating system presented significantly higher bond strength to ceramic/metal and metal substrates.

\section{References}

1. Blixt M, Adamczak E, Lindén L, Odén A, Arvidson K. Bonding to densely sintered alumina surfaces: effect of sandblasting and silica coating on shear bond strength of luting cements. Int J Prosthodont. 2000;13(3):221-6.

2. Chong KH, Chai J, Takahashi Y, Wozniak W. Flexural strength of in-ceram alumina and in-ceram zirconia core materials. Int J Prosthodont. 2002;15(2):183-8.

3. Della Bona A, Anusavice KJ. Microstructure, composition, and etching topography of dental ceramics. Int J Prosthodont. 2002;15(2):159-67.

4. Della Bona A, Anusavice KJ, Hood JAA. Effect of ceramic surface treatment on tensile bond strength to a resin cement. Int J Prosthodont. 2002;15(3):248-53.

5. Della Bona A, Anusavice KJ, Shen C. Microtensile strength of composite bonded to hot-pressed ceramics. J Adhes Dent. 2000;2(4):305-13.
Kern, Strub ${ }^{14}$ (1998) performed a clinical study to evaluate the bonding of resin to alumina-based ceramic, employing silica coating as the ceramic surface treatment. The patients were recalled every 6 months for evaluation of the restorations. During a 5 -year period, there were some failures due to ceramic fracture, yet there was no failure in the ceramic-resin-enamel bonding interface. These findings agree with the results from the qualitative analysis of fractured surfaces in the present study, which showed cohesive fracture at the adhesive interface for all specimens. This is observed by the small areas of resin on the ceramic surface, which were in higher quantity and/or larger for the SC-treated specimens compared to the HF- and SB-treated samples. These observations are in agreement with the bond strength values obtained for the different surface treatments $(\mathrm{SC}>\mathrm{SB}>\mathrm{HF})$, regardless of the type of test.

\section{Conclusion}

The results confirmed the study hypothesis that silicatization of the IZ ceramic produces higher mean tensile and shear bond strength values to composite resin than HF-etching or sandblasting with aluminum oxide particles. Although the mean $\sigma_{t}$ and $\sigma_{\mathrm{s}}$ values were different for the same experimental groups, the statistical ranking of the mean values was similar for both tests.

6. Della Bona A, Shen C, Anusavice KJ. Work of adhesion of resin on treated lithia disilicate-based ceramic. Dent Mater. 2004;20(4):338-44.

7. Della Bona A, Van Noort R. Shear versus tensile bond strength of resin composite bonded to ceramic. J Dent Res. 1995;74(9):1591-6.

8. Dérand P, Dérand T. Bond strength of luting cement to zirconium oxide ceramics. Int J Prosthodont. 2000;13(2):131-5.

9. Frankenberger R, Krämer N, Sindel J. Repair strength of etched $v$ s. silica-coated metal-ceramic and all-ceramic restorations. Oper Dent. 2000;25(3):209-15.

10. Giordano RA, Pelletier L, Campbell S, Pober R. Flexural strength of an infused ceramic, glass ceramic, and feldspathic porcelain. J Prosthet Dent. 1995;73(5):411-8. 
11. Guazzato M, Albakry M, Swain MV, Ironside J. Mechanical Properties of In-Ceram Alumina and In-Ceram Zirconia. Int J Prosthodont. 2002;15(4):339-46.

12. Haselton DR, Diaz-Arnold AM, Dunne JT Jr. Shear bond strengths of 2 intraoral porcelain repair systems to porcelain or metal substrates. J Prosthet Dent. 2001;86(5):526-31.

13. Haselton DR, Diaz-Arnold AM, Hillis SL. Clinical assessment of high-strength all-ceramic crowns. J Prosthet Dent. 2000;83(4):396-401.

14. Kern M, Strub JR. Bonding to alumina ceramic in restorative dentistry: clinical results over up to 5 years. J Dent. 1998;26(3):245-9.

15. Kern M, Thompson VP. Bonding to glass infiltrated alumina ceramic: Adhesive methods and their durability. J Prosthet Dent. 1995;73(3):240-9.

16. Kern M, Thompson VP. Sandblasting and silica coating of a glass-infiltrated alumina ceramic: volume loss, morphology, and changes in the surface composition. J Prosthet Dent. 1994;71(5):453-61.

17. Özcan M, Alkumru HN, Gemalmaz D. The effect of surface treatment on the shear bond strength of luting cement to a glass-infiltrated alumina ceramic. Int J Prosthodont. 2001;14(4):335-9.

18. Özcan M, Vallittu PK. Effect of surface conditioning methods on the bond strength of luting cements to ceramics. Dent Mater. 2003;19(8):725-31.

19. Pröbster L. Four year clinical study of glass-infiltrated, sintered alumina crowns. J Oral Rehabil. 1996;23(3):147-51.

20. Sadoun M, Asmussen E. Bonding of resin cements to an aluminous ceramic: a new surface treatment. Dent Mater. 1994;10(3):185-9.

21. Sorensen JA, Kang SK, Torres TJ, Knode H. In-Ceram fixed partial dentures: Three-year clinical trial results. J Calif Dent Assoc. 1998;26(3):207-14.

22. Valandro LF, Della Bona A, Bottino MA, Neisser MP. The effect of ceramic surface treatment on bonding to densely sintered alumina ceramic. J Prosthet Dent. 2005;93(3):2539.

23. Wood DJ, Bubb NL, Millar BJ. Preliminary investigation of a novel system for hydrofluoric acid etch-resistant dental ceramics. J Prosthet Dent. 1997;78(3):275-80. 